\title{
Intervensi Psikologi di Layanan Kesehatan Primer
}

\author{
Anita Novianty ${ }^{1}$, Sofia Retnowati \\ Universitas Kristen Krida Wacana ${ }^{1}$, Fakultas Psikologi UGM ${ }^{2}$
}

\begin{abstract}
The prevalence of mental disorder is growing up every year and highly contributed on global mental health burden. Yet the people who got professional treatment was below average. There was a gap between the high prevalence of mental disorder cases and the number of people who got the proper treatment. Some literature reviews showed that patients with psychiatric symptom were found out in primary health care, but mostly the case was not recognized by health workers due to lack of knowledge and skills on mental health issues, as well as the fear of stigma by the patients. The delay on detection of mental disorder onset will affect the prognosis of patient's mental health. It is indicated the real emergency on detecting mental disorder symptoms and delivering the initial psychological intervention at primary health care level. This paper highlighted the high prevalence of mental disorder cases in primary health care, evidence based psychological interventions that have been used to treat the mental disorder cases in primary health care, as well as the challenges and the opportunities of psychological intervention in primary health care from some literature reviews.
\end{abstract}

Keywords: mental disorder, psychological intervention, primary health care

\section{Pengantar}

Salah satu tantangan yang saat ini dihadapi oleh masyarakat global maupun pemangku kepentingan terutama di bidang kesehatan mental adalah prevalensi gangguan mental yang terus meningkat tiap tahunnya. Pada tahun 1990, gangguan mental dan neurologis berkontribusi sebesar $10 \%$ dari total Disability-Adjusted Life Years (DALY), kemudian pada tahun 2000 menjadi sebesar $12 \%$, dan diperkirakan terus akan meningkat hingga $15 \%$ pada tahun 2020 (World Health Organization, 2001). Menurut Harvey dan Gumport (2015) masalah global terkait kesehatan mental yang masih dihadapi saat ini yaitu prevalensi gangguan mental yang tinggi

Korespondensi mengenai isi artikel ini dapat dilakukan melalui: novianty.anita@gmail.com atau anita_novianty@ugm.ac.id dan terus meningkat, mayoritas individu yang terdiagnosis gangguan mental tidak mampu mengakses penanganan yang tepat, dan walaupun terdapat bukti bahwa penanganan psikologis berbasis empiris efektif, namun aksesnya terbatas.

Gangguan mental secara tidak langsung juga memengaruhi beban sosial (Mueser \& McGurk, 2004) dan beban ekonomi nasional (Ngui, Khasakhala, Ndetei, \& Roberts, 2010). Gangguan mental tidak hanya merupakan kondisi medis yang memiliki prevalensi tinggi, namun juga memiliki tingkat disabilitas yang tinggi terutama di negara-negara dengan pendapatan rendah (Burns, 2014; Patel, 2007). Pada saat ini dari 450 ribu orang diperkirakan terdapat satu orang yang mengalami gangguan mental (McBain, Salhi, Morris, Salomon, \& Betancourt, 2012). Prevalensi individu dengan gangguan 
mental secara global sangat tinggi, namun jumlah individu yang mendapatkan penanganan profesional kurang dari $10 \%$ di negara-negara dengan pendapatan menengah ke bawah (McBain et al., 2012). Tingginya angka beban tersebut salah satunya dikarenakan banyaknya individu tidak mendapatkan penanganan yang tepat di layanan spesialis maupun layanan kesehatan secara umum (Kohn, Saxena, Levav, \& Saraceno, 2004).

Hasil Riset Kesehatan Dasar (Riskedas) menunjukkan prevalensi gangguan jiwa berat nasional sebesar 1,7 per mil, yang artinya 1-2 orang dari 1000 penduduk Indonesia mengalami gangguan jiwa. Prevalensi penduduk yang mengalami gangguan mental emosional secara nasional pada tahun 2013 sebesar 6\% (37.728 orang dari subjek yang dianalisis). Prevalensi tertinggi ada pada kelompok usia lebih dari 75 tahun dibandingkan kelompok usia lainnya, kelompok perempuan daripada laki-laki, dan kelompok tidak sekolah (Kementerian Kesehatan RI, 2013).

Temuan tingginya prevalensi individu dengan gangguan mental, dan minimnya individu yang memeroleh perawatan formal mengindikasikan adanya 'treatment gap' (kesenjangan penanganan). Kesenjangan penanganan merujuk pada prevalensi gangguan mental yang terjadi dan proporsi individu yang tertangani, atau dengan kata lain persentase individu yang memerlukan perawatan, namun tidak menerima penanganan. Hambatan eksternal dapat menjadi salah satu penyebab tingginya kesenjangan penanganan. Hal ini dapat ditinjau dari akses yang meliputi area geografis, transportasi, dan biaya ke layanan kesehatan mental tidak terdistribusi secara merata (Harvey \& Gumport, 2015). Di Indonesia, standar yang belum memadai antara jumlah tenaga profesional kesehatan mental (psikolog dan psikiater) dengan jumlah penduduk menjadi salah satu penghambat akses layanan kesehatan mental (Kementerian Kesehatan RI, 2013).

Usaha yang dilakukan untuk menjembatani kesenjangan penanganan yaitu dengan meningkatkan jumlah dan mutu tenaga kesehatan mental profesional di institusi pendidikan, integrasi pembiayaan pelayanan melalui asuransi kesehatan, pemberdayaan masyarakat (Dinas Kesehatan DIY, 2015) dan integrasi layanan kesehatan mental di aras primer (Dinas Kesehatan DIY, 2015; Retnowati, 2011). Mclnnis dan Merajver (2011) mengemukakan bahwa usaha lain untuk mengurangi kesenjangan penanganan adalah dengan melatih tenaga non-profesional berbasis komunitas untuk mengenali dan mendapatkan pengetahuan tentang kesehatan mental, serta berkolaborasi dengan para tenaga pemberi bantuan informal di komunitas. Program kesehatan mental berbasis komunitas yang telah dilakukan yaitu program Desa Siaga Sehat Jiwa (DSSJ) di Yogyakarta (Putri et al., 2013) dan di Aceh (Widiyani, 2013).

Beberapa alasan mengapa perlu ada layanan psikoterapi di layanan kesehatan primer yaitu (a) suatu situasi di mana yang hanya dapat memberikan penanganan adalah intervensi non-farmakologi (misal seperti dissociative disorder); (b) ketika tidak teramati adanya gangguan psikiatris, namun pasien menunjukkan kesehatan mental yang rendah (misalnya, harga diri yang rendah); (c) tekanan yang berkaitan dengan gejala fisik atau meningkatkan keluhan fisik (misal tekanan yang menyebabkan asma kambuh/semakin memperburuk asma pasien); (d) ketika adanya efek samping dari obat psikotropika sehingga diperlukan intervensi dampingan (semisal, psikoterapi diperlukan untuk mengurangi gejala depresi); (e) ketika ada kecenderungan untuk menyakiti diri sendiri 
(penggunaan obat-obatan akan bahaya karena dapat berdampak overdosis), dan (f) untuk meningkatkan kepatuhan akan pengobatan (Russel, Russel, Kaur, Nair, \& Darilin, 2012).

Tulisan ini ingin mengetahui kasus gangguan mental yang sering ditemui di layanan kesehatan primer, intervensi psikologi yang diberikan, serta tantangan dan peluang intervensi psikologi di layanan kesehatan primer. Tulisan ini menyajikan penelitian terkini dan ide-ide yang diusulkan dan dikembangkan di beberapa negara terkait dengan penerapan intervensi psikologi di layanan kesehatan primer. Harapannya agar ide atau program yang telah dikembangkan dan diteliti di negara lain tersebut dapat dijadikan pembelajaran bersama bagi peneliti dan praktisi kesehatan mental di Indonesia.

\section{Pembahasan}

Kasus Gangguan Mental di Layanan Kesehatan Primer

Ansseau et al. (2004) meneliti mengenai prevalansi gangguan mental yang sering muncul di layanan kesehatan primer di Belgia dengan cara mengumpulkan data dari jawaban-jawaban pasien dan diagnosis yang dilakukan oleh dokter umum. Hasilnya menunjukkan bahwa prevalensi gangguan mental tertinggi terjadi pada wanita dibandingkan pria. Seperti halnya yang terjadi di Indonesia, pasien datang ke layanan kesehatan primer pada awalnya disebabkan oleh keluhan-keluhan fisik. Berdasarkan hasil kajian ditemukan bahwa prevalensi gangguan-gangguan psikologis yang paling sering muncul yaitu gangguan depresi mayor (13.9\%), Dysthymia (12,6\%), Multisomatoform disorder NOS (10,7 \%), Generalized anxiety disorder (10,3\%) dan gangguan alkohol (10.1\%). Adapun perbedaan prevalensi ini juga didasari adanya 50 perbedaan jender, seperti halnya depresi, kecemasan, somatoform dan gangguan makan paling signifikan terjadi pada perempuan daripada laki-laki, sementara itu gangguan alkohol sering terjadi pada laki-laki.

Penelitian serupa juga dilakukan oleh Roca, et al. (2009) yang melakukan studi epidemiologi nasional untuk mengetahui prevalensi gangguan mental yang paling sering muncul di Spanyol. Data dikumpulkan dari layanan kesehatan primer dalam skala nasional, dan ditemukan hasil prevalensi gangguan mental pada wanita lebih tinggi dari pria, terkecuali untuk gangguan alkohol. Gangguan mental yang sering muncul yaitu depresi, nonspesific somatoform disorder, dysthymia, multisomatoform disorder, dan Generalized anxiety disorder. Dari beberapa hasil penelitian sebelumnya dapat dilihat bahwa prevalensi gangguan mental yang sering muncul atau dikeluhkan di layanan kesehatan primer adalah depresi, kecemasan, dan somatoform, dan juga prevalensi gangguan mental pada wanita lebih tinggi dari pria (Ansseau et al., 2004; Grandes, Montoya, Arietaleanizbeaskoa, Arce, \& Sanchez, 2011; Roca et al., 2009). Grandes et al. (2011) menambahkan bahwa pada usia rata-rata 40 tahun ke atas prevalensi gangguan mental yang sering terjadi adalah ganguan mood, sementara pada usia ratarata 30 tahun adalah kecemasan. Data tersebut menunjukkan bahwa layanan kesehatan primer tidak cukup hanya memberikan layanan untuk kesehatan fisik saja, namun ada kebutuhan akan penyedia layanan psikologi. Ansseau et al. (2004) menyatakan meskipun hanya $5,4 \%$ pasien yang mengunjungi dokter umum untuk kondisi-kondisi psikologis, namun pada kenyataannya didapatkan hampir 40\% pasien memenuhi kriteria gangguan psikiatris. Adanya kesenjangan antara alasan 
pasien datang ke dokter umum dan diagnosis yang aktual kemungkinan disebabkan oleh beberapa faktor yaitu level dokter umum yang memiliki waktu yang terbatas untuk mewawancarai pasien, pengetahuan yang belum memadai mengenai prosedur diagnosis, sering men"somatisasi"-kan gangguan-gangguan mental, dan kurangnya empati pada pasien dengan gangguan psikiatrik. Sementara di level pasien, adanya penolakan untuk mengkonsultasikan keadaan psikologis mereka akibat kekhawatiran dengan stigma. Adanya kesenjangan di kedua level ini menyebabkan simtom-simtom gangguan psikologis di atas tidak tertangani dengan tepat.

Stigmatisasi terhadap individu dengan gangguan kesehatan mental tidak hanya terjadi di masyarakat umum, akan tetapi juga terjadi di kalangan profesional kesehatan. Penelitian Corrigan, Mittal, Reaves, Haynes, Han, Morris, dan Sullivan (2014) menunjukkan bahwa ada kecenderungan dari profesional kesehatan (perawat dan dokter) yang memiliki stigma pada pasien dengan gangguan mental mempunyai persepsi bahwa pasien tersebut tidak akan patuh dengan pengobatan mereka, dan persepsi ketidakpatuhan ini nantinya akan berdampak pada keputusan layanan kesehatan yang mereka berikan (merujuk pada spesialis atau memberikan obat medis).

Ditemukan pula bahwa latar disiplin ilmu dari tenaga profesional kesehatan tersebut juga memengaruhi kenyamanan dan pengenalan mereka terhadap gangguan kesehatan mental. Implikasi penelitian ini bahwa pengetahuan mengenai kesehatan mental perlu diberikan pada profesional kesehatan lainnya di layanan kesehatan primer sehingga mereka lebih dapat menerima pasien dengan gangguan mental, mengerti bagaimana mengambil keputusan akan penanganan orang dengan gangguan mental, dan mengurangi stigma untuk mempromosikan kesehatan mental pada masyarakat (Corrigan et al., 2014).

\section{Intervensi Psikologi untuk Pasien dengan Gangguan Mental}

Menurut Hanlon, Fekadu, dan Patel (2014), salah satu kesenjangan penanganan global yang terjadi adalah kenihilan terapi untuk menangani gangguan mental, neurologis, penggunaan obat-obatan (atau biasanya disebut MNS Disorders: Mental, Neurological, and Substance Use), terutama yang berbasis bukti empiris. Penanganan untuk MNS disorders sulit dan terlalu kompleks untuk ditangani, terutama pada setting yang kekurangan sumber daya. Selain itu, sebagian besar masyarakat lebih memercayakan penanganan pada cara-cara tradisional, keagamaan ataupun budaya setempat yang masih kontroversial mengenai efektivitasnya (Hanlon et al., 2014). Adapun yang termasuk dalam gangguan mental, neurologis, dan penggunaan obat-obatan yaitu depresi, gangguan penggunaan alkohol dan obat-obatan, bunuh diri dan perilaku menyakiti diri sendiri, psikosis, gangguan bipolar, epilepsi, dementia, dan gangguan perkembangan dan perilaku anak-anak. Hanlon et al. (2014) memberikan gambaran mengenai prinsip-prinsip sebuah intervensi bahwa penggunaan intervensi terhadap kriteria gangguan mental apapun seharusnya memerhatikan efektivitas, kemungkinan untuk diimplementasikan, keadilan, berterima secara sosial dan budaya, dan dapat terjangkau. Di bawah ini merupakan salah satu intervensi yaitu intervensi psikologis yang digunakan untuk menangani MNS disorders secara umum yang ditulis oleh Hanlon et al. (2014).

\section{First-Line Psychological Interventions}

Intervensi psikologis ini dapat diberikan oleh non-spesialis dengan minimal memiliki 
pengalaman di bidang kesehatan mental. Terdapat dua contoh jenis intervensi psikologis ini yaitu psychological first aid dan psikoedukasi (Hanlon et al., 2014).

\section{Psychological First Aid}

Psychological first aid merupakan intervensi yang ditujukan pada anggota masyarakat untuk meningkatkan pengetahuan dan pemahaman mereka tentang gangguan kesehatan mental, mengurangi stigmatisasi dan membekali masyarakat dengan keterampilan-keterampilan sederhana untuk menolong orang lain di sekitarnya yang mengalami gangguan mental (melakukan pengiraan resiko bunuh diri atau perilaku menyakiti diri sendiri, mendengarkan tanpa menghakimi, memberikan penguatan dan informasi, mendorong untuk mencari bantuan dari profesional dan menggunakan teknik menolong diri sendiri) (Hanlon et al., 2014).

Menurut Ruzek, Brymer, Jacobs, Layne, Vernberg, dan Watson (2007), psychological first aid terdiri dari suatu susunan sistematis tindakan menolong yang bertujuan untuk mengurangi tekanan pasca trauma awal dan mendukung fungsi adaptif jangka pendek dan jangka panjang. Apabila psychological first aid digunakan dalam desain awal dalam menanggapi bencana/trauma, maka psychological first aid dapat dikonstruksikan ke dalam delapan aksi utama yaitu: kontak dan keterlibatan, keamanan dan kenyamanan, stabilisasi, pengumpulan informasi, pendampingan, keterhubungan dengan dukungan sosial, informasi terhadap dukungan pengatasan masalah, dan keterhubungan dengan layanan ko-laboratif (Ruzek, et al., 2007).

\section{Psikoedukasi}

Psikoedukasi merupakan intervensi untuk pasien dan perawat pasien yang diberikan untuk meningkatkan pemahaman mereka mengenai gangguan mental, penanganannya, dan mengevaluasi orang yang dapat memengaruhi kesembuhan pasien secara maksimal. Tujuannya adalah untuk memengaruhi perubahan perilaku, contohnya meningkatkan kepatuhan pengobatan, yang diasosiasikan dengan luaran yang lebih baik (Hanlon et al., 2014).

Penelitian yang dilakukan oleh Bossema, de Haar, Westerhuis, Beenackers, Blom, Appels, dan van Oeveren (2011) menemukan bahwa psikoedukasi yang diberikan pada pasien dengan gangguan psikotik dapat meningkatkan pengetahuan dan pengatasan masalah. Pasien dengan kriteria skor basal rendah, edukasi menengah/tinggi, dan menggunakan pengobatan antipsikotik tipikal lebih mendapat keuntungan dari psikoedukasi dibandingkan pasien dengan skor basal tinggi, edukasi rendah, dan menggunakan pengobatan antipsikotik atipikal (Bossema et al., 2011).

Walaupun selama ini psikoedukasi dikritik tidak memberikan hasil yang efektif, akan tetapi kajian literatur sistematis yang dilakukan oleh Tursi, Baes, Camacho, Tofoli, dan Juruena (2013) menunjukkan bahwa psikoedukasi sebagai penanganan psikososial dapat meningkatkan pengetahuan mengenai depresi dan penanganannya yang berasosiasi dengan prognosis yang lebih baik dan pengurangan beban psikososial bagi keluarga (Tursi et al., 2013). Sejalan dengan itu, kajian metaanalisis oleh Donker, Griffiths, Cuijpers, dan Christensen (2009) menunjukkan bahwa psikoedukasi sebagai intervensi tahap awal pada mereka yang mengalami tekanan psikologis atau depresi dapat mengurangi gejala depresi. Intervensi ini dikatakan mudah untuk diimplementasikan, dapat diterapkan segera dan tidak mahal, maka dari itu cocok digunakan sebagai intervensi awal di layanan primer (Donker et al., 2009). Buletin Psikologi 


\section{Structured, Brief Psychological Therapies}

Structured, brief psychological therapies merupakan model penanganan yang berbatas waktu dan biasanya memiliki manual untuk memastikan akurasinya. Contohnya cognitive behavior therapy, behavioral activation, interpersonal psychotherapy, problem solving therapy, dan relaxation therapy. Kebanyakan terapi ini digunakan dalam manajemen gangguan depresi dan kecemasan, tetapi juga efektif dalam menangani gangguan bipolar, mengurangi beberapa gejala skizofrenia dan penyalahgunaan obat-obatan. Dibandingkan dengan first-line psychological intervention lainnya, pendekatan ini lebih formal dan dibangun atas dasar teori-teori psikologi mengenai gangguan mental, memerlukan pelatihan terapis yang lebih, dan biasanya diberikan oleh spesialis kesehatan mental atau non-spesialis dengan supervisi spesialis di tingkat yang lebih tinggi (Hanlon et al., 2014).

\section{Cognitive Behavior Therapy (CBT)}

Berdasarkan model gangguan mental di mana pikiran-pikiran negatif mengenai diri, dunia dan masa depan, dan berasosiasi dengan perilaku yang maladaptif, dapat mengarahkan dan menjaga tekanan emosional. Terapi ini membantu klien dengan mengidentifikasi di mana proses berpikir mereka yang salah, menantang asumsi yang melandasi pikiran negatif mereka dan mengubah perilaku mereka. Behavioral activation merupakan salah satu komponen dari Cognitive Behavior Therapy (CBT) yang dapat juga dijadikan metode independen dalam terapi. Behavioral activation berfokus untuk mendorong klien secara aktif mengatur waktunya, mengelola kembali aktivitas rutinnya yang selama ini hilang, dan yang terpenting memaparkan pada mereka pengalaman-pengalaman potensial yang menyenangkan. Beberapa studi Buletin Psikologi mengindikasikan bahwa Behavioral Activation seefektif CBT, dan lebih lugas untuk disampaikan pada klien, terutama yang memiliki sumber daya terbatas (Hanlon et al., 2014).

CBT dikatakan terbukti efektif menangani berbagai macam kasus gangguan mental dari gangguan yang umum hingga psikosis, bahkan diklaim lebih efektif dibandingkan jenis psikoterapi lainnya atau intervensi dengan menggunakan obat terutama pada pasien depresi dan kecemasan (Tolin, 2010). Walaupun pada beberapa kasus, salah satunya klien minoritas, klien CBT seringkali mengalami 'drop out' atau menghentikan proses terapi (Rathod, Kingdon, Smith, \& Turkington, 2005).

Interpersonal Psychotherapy (IPT)

Interpersonal Psychotherapy (IPT) berfokus pada konteks interpersonal depresi. Empat tipe kesulitan interpersonal yang berkontribusi signifikan pada perkembangan depresi: duka, ketidaksepakatan antar pribadi, pergeseran peran (contoh: menjadi Ibu rumah tangga, pensiun), dan defisit interpersonal (contohnya, isolasi sosial dan kesepian). Terapi ini bertujuan untuk meningkatkan komunikasi interpersonal dan pengambilan keputusan dalam kaitannya dengan masalah yang dihadapi dan mengurangi gejala-gejala (Hanlon et al., 2014).

Kajian meta-analisis yang dilakukan oleh Cuijpers, Geraedts, van Oppen, Andersson, Markowitz, dan van Straten (2011) menemukan bahwa IPT baik secara independen maupun kombinasi dengan farmakoterapi efektif dalam menangani depresi. Bahkan penanganan kombinasi IPT dan farmakoterapi lebih efektif dalam mencegah relapse dibandingkan hanya penanganan farmakoterapi saja (Cuijpers et al., 2011). 


\section{Problem-Solving Therapy}

Dalam Problem-solving Therapy terdapat beberapa tahapan terstruktur yaitu klarifikasi dan mendefinisikan permasalahan, pilihan akan tujuan yang dapat dicapai, berbagai pilihan solusi, solusi yang dipilih, implementasi pilihan solusi, dan evaluasi. Tujuan terapi ini untuk membantu pasien meningkatkan keterampilan-keterampilan diri dan sumber daya untuk menghadapi sumber tekanan psikososial yang berkontribusi pada kondisi kesehatan mentalnya (Hanlon et al., 2014).

\section{Relaxation Therapy}

Teknik relaksasi termasuk pelatihan relaksasi otot progresif, relaksasi imajinasi, biofeedback, dan teknik-teknik dari meditasi dan yoga. Keuntungannya adalah apabila sudah dipelajari dan menguasai maka dapat digunakan tanpa adanya supervisi dari profesional. Selain itu terapi relaksasi dapat diberikan oleh non-spesialis yang sudah terlatih, bahkan pekerja non-kesehatan sekalipun (Hanlon et al., 2014).

Sebuah studi yang meneliti mengenai relaksasi (relaksasi otot, kesadaran indera, dan yoga) untuk mengurangi keluhan fisik dalam desain eksperimen menunjukkan bahwa walaupun hasil analisis statistik tidak menemukan adanya perbedaan antara kelompok eksperimen dan kontrol dalam hal ketegangan secara umum, namun terlihat ada penurunan ketegangan kelompok kontrol lebih sedikit dari kelompok eksperimen (yaitu pada kelompok relaksasi otot). Keuntungan teknik ini adalah penggunaannya yang mudah dan praktis. Sehingga relaksasi dapat direkomendasikan untuk dapat mengurangi keluhan fisik, walaupun kurang efektif dalam menurunkan ketegangan (Prawitasari, 2011).
Efikasi dan Efektivitas Psikoterapi di Layanan Kesehatan Primer

Russel et al. (2012) menuliskan bahwa psikoterapi yang terdiri dari elemen science dan art merupakan salah satu intervensi utama dalam menangani kesehatan mental anak-anak dan remaja. Psikoterapi merupakan salah satu praktik medis maka dari itu seperti halnya dengan prosedur medis lainnya, layanan psikoterapi perlu ada di layanan kesehatan primer yang mudah terjangkau oleh masyarakat.

Depresi merupakan salah satu gangguan mental yang umum terjadi, dan ditangani dengan berbagai pendekatan psikoterapi di layanan kesehatan primer, namun masih sedikit studi follow-up untuk mengetahui efektivitas psikoterapi dalam menangani kasus depresi dalam kaitannya dengan jangka waktu munculnya kembali gejala-gelaja depresi tersebut (relapse rate). Steinert, Hofmann, Kruse, dan Leichsenring (2014) melakukan studi analisis terhadap penelitian mengenai depresi untuk mengetahui jangka waktu relapse pasien depresi dan membandingkan antara psikoterapi dan intervensi non-psikoterapi pada pasien depresi. Dari hasil penelitian ini ditemukan bahwa sekitar $40 \%$ pasien yang sebelumnya diberi penanganan berupa psikoterapi memiliki setidaknya satu kali kemunculan gejala depresi pada follow-up jangka panjang.

Apabila dibandingkan dengan intervensi non-psikoterapeutik lainnya (farmakologi dan penanganan biasa) pasien yang mendapatkan psikoterapi lebih sedikit mengalami relapse dibandingkan yang tidak mendapatkan psikoterapi. Hal ini mendukung kritikan dari Harvey dan Gumport (2015) bahwa pengobatan medis biasanya lebih berfokus pada penghilangan gejalagejala, namun intervensi psikologis lebih pada penguatan individu sehingga yang memungkinkan menjadi salah satu faktor 
mengapa relapse pada pasien dengan psikoterapi lebih rendah daripada intervensi dengan obat dan penanganan biasa.

Wolf dan Hopko (2008) mengulas mengenai data hasil intervensi psikososial dan farmakologi di layanan primer untuk penanganan depresi. Berdasarkan kesimpulan secara umum bahwa psikoterapi, farmakoterapi, dan model perawatan kolaboratif lebih unggul dibandingkan perawatan biasa. Dari 10 studi mengenai psikoterapi dan farmakoterapi, enam studi diantaranya menunjukkan hasil luaran yang relatif sama antara psikoterapi dan farmakoterapi. Tiga studi menunjukkan hasil farmakoterapi lebih menguntungkan, dan satu studi menunjukkan psikoterapi yang lebih menguntungkan.

Dalam penelitian ini terdapat beberapa hal yang dapat disimpulkan mengenai efikasi penanganan spesifik di layanan kesehatan primer yaitu problem solving therapy dan interpersonal therapy dianggap intervensi yang kemungkinan memiliki efikasi terhadap depresi minor dan dysthymia. Sementara itu, cognitive behavior therapy memiliki efikasi sebagai intervensi untuk menangani depresi mayor dan depresi minor atau dysthymia. Psikoterapi menunjukkan hasil seefektif farmakoterapi, bahkan diindikasikan rata-rata mengalami relapse lebih rendah dibandingkan farmakoterapi (Wolf \& Hopko, 2008; Steinert et al., 2014). Efikasi psikoterapi kognitif-perilakuan (Cognitive Behavioral Psychotherapy) yang dilakukan sebanyak delapan kali tatap muka selama 60 menit setiap sesinya diaplikasikan oleh psikolog di layanan kesehatan primer pada pasien gangguan kecemasan-depresif menunjukan hasil pasien merasa lebih nyaman untuk datang ke layanan kesehatan primer dibandingkan ke layanan kesehatan mental (Jauregui et al., 2015).
Kenyataannya di lapangan, perlu teknik khusus yang dilakukan di layanan kesehatan primer. Hal ini dikarenakan pasien yang datang ke layanan kesehatan primer biasanya menginginkan penanganan dalam jangka waktu pendek dengan 1-2 kali pertemuan dan setiap pertemuan berkisar 15 menit. Sehingga penggunaan brief psychotherapy di layanan kesehatan primer meluas di berbagai negara. Psikoterapi singkat ini dapat mencegah gejala-gejala yang dialami pasien menjadi semakin parah atau menyebar menjadi gejala lainnya. Russel et al. (2012) memberikan gambaran mengenai adanya perbedaan penggunaan psikoterapi di setting sekunder dan tersier dengan layanan kesehatan primer, seperti yang dapat dilihat di Tabel 1.

Tantangan Intervensi Psikologi di Layanan Kesehatan Primer

Verdoux, Cortaredona, Dumesnil, Sebbah, dan Veryer (2014) meneliti opini 2114 dokter umum terhadap psikoterapi, ditemukan jawaban bahwa kebanyakan doker umum beropini psikoterapi efisien untuk digunakan sebagai penanganan depresi dan menyetujui bahwa psikoterapi dapat menjadi intervensi independen untuk menangani pasien depresi ringan hingga moderat. Kebanyakan dokter umum menyatakan bahwa psikoterapi lebih cocok digunakan untuk pasien dengan level pendidikan tinggi. Hampir setengah jumlah responden sangat setuju dengan pendapat bahwa terjadi pemberian resep di luar batas untuk obat anti-depressant. Ditemukan juga kendala terkait akses psikoterapi, yang hanya dapat diadministrasikan oleh psiko$\log$ atau psikoterapis swasta yang tidak dapat dibayarkan oleh asuransi/tidak ditanggung negara. Selain itu juga terdapat kesulitan dalam membedakan berbagai tipe intervensi psikoterapi, dan adanya keengganan dari pasien untuk menggunakan 
Tabel 1

Perbedaan-perbedaan antara psikoterapi di layanan primer dan setting yang lain

\begin{tabular}{|c|c|c|}
\hline \multirow{2}{*}{ Komponen } & \multicolumn{2}{|c|}{ Setting Psikoterapi } \\
\hline & Secondary/Tertiary Care & Primary Care \\
\hline Model & Restrukturisasi, re-edukasi & Suportif, Problem Solving \\
\hline Sesi & Beragam & 1 atau 2 \\
\hline Durasi Sesi & $40-45$ menit & 22-25 menit \\
\hline Jadwal Kunjungan Reguler & Sesi terencanakan & $\begin{array}{l}\text { Tidak selalu harus } \\
\text { direncanakan }\end{array}$ \\
\hline Formulasi Kasus & Berorientasi pada "insight" & $\begin{array}{l}\text { Berorientasi pada problem- } \\
\text { coping }\end{array}$ \\
\hline Model Pendekatan & $\begin{array}{l}\text { Psikodinamika, Kognitif, } \\
\text { Bermain, Keluarga }\end{array}$ & Perilaku \\
\hline Fokus pada Di sini dan Saat in & Orientasi 'insight' masa lalu & Gejala di sini dan saat ini \\
\hline Membuat Koneksi & Dianjurkan & Dianjurkan \\
\hline Mendorong Aktivitas Pasien & Dianjurkan & Dianjurkan \\
\hline Memanipulasi Lingkungan & Jarang dilakukan & Sering dilakukan \\
\hline Landasan Terapi & Psikopatologi & Kesehatan \\
\hline Hubungan Terapeutik & Hubungan Terapeutik & Teknik Terapeutik \\
\hline Intensitas & Tinggi & Rendah \\
\hline Kecocokan Pasien-Terapis & Penting & Tidak terlalu penting \\
\hline Mendengarkan Empatik & Sangat reflektif & Sangat reflektif \\
\hline Ekspektasi & Harus dieksplorasi & Tidak selalu dieksplorasi \\
\hline Komunikasi Efektif & Dianjurkan & Dianjurkan \\
\hline Proses Perubahan & Didiskusikan & Didiskusikan \\
\hline Pengaturan batas & Ditegakkan secara ketat & Ditegakkan tidak secara ketat \\
\hline
\end{tabular}

Sumber: Russel, S., Russel, P. S., Kaur, M. S. D., Nair, M. K. C., \& Darilin, D. (2012). Priority mental health disorders of children and adolescents in primary-care pediatric settings in India 3: Psychotherapy and other non-pharmacological interventions. Indian Journal of Pediatrics, 79(1), p.S37.

layanan psikoterapi yang kemungkinan besar diakibatkan oleh stigma (Verdoux et al., 2014).

Stigma tidak hanya terjadi pada masyarakat umum dikarenakan di beberapa tempat literasi kesehatan mental masih rendah, namun juga adanya stigma di antara kalangan profesional kesehatan di layanan kesehatan primer itu sendiri (Corrigan et al., 2014). Untuk itu perlu adanya pelatihan untuk meningkatkan pengetahuan mengenai gangguan mental dan penanganannya di kalangan profesional kesehatan. Goncalves et al. (2013) membuat model untuk memberikan pengenalan tentang gangguan mental dan kesesuaian rujukan ke spesialis pada dokter umum, perawat, pekerja sosial, psikolog dan pikiater. Hasil dari pelatihan ini berbeda-beda, misalnya terjadi peningkatan pada kemampuan pengenalan gangguan mental pada perawat, namun tidak pada tenaga profesional yang lain. Namun ada perubahan yang terjadi yaitu penggunaan pendekatan berpusat pada klien di layanan kesehatan primer. 
Penerapan Psikoterapi untuk Populasi Status Ekonomi Rendah

Kemiskinan dan diskriminasi dapat menyebabkan gangguan mental seperti depresi mayor (Krupnick \& Melnikoff, 2012) dan meningkatnya angka bunuh diri (Reifels, Bassilios, Nicholas, Fletcher, King, Ewen, \& Pirkis, 2015). Namun populasi tersebut justru jarang mendapatkan layanan kesehatan mental yang disebabkan adanya beberapa hambatan yaitu; (a) Hambatan praktis seperti biaya, transportasi (biaya yang dibutuhkan untuk tiba di tempat terapi), waktu/ jam klinik terbatas (biasanya waktu layanan psikoterapi adalah hari kerja di mana berbenturan dengan waktu kerja mereka), lokasi klinik yang jauh, dan kesulitan untuk mencari pengasuhan anak selama mereka dalam sesi terapi; (b) Hambatan Psikologis seperti adanya stigma, kurangnya tenaga profesional kesehatan lainnya untuk menanyakan keadaan emosi pasien dikarenakan keterbatasan waktu, ketidaktahuan tenaga profesional kesehatan lain mengenai jalur rujukan yang tepat bila menemukan indikasi gangguan mental pada pasien; dan (c) Hambatan budaya/ ras/ etnik seperti perbedaan bahasa, perbedaan ras/etnik terapis-pasien, kurangnya komunikasi dan pemahaman budaya, perbedaan status ekonomi, pengalaman diskriminasi di masa lalu di layanan kesehatan, dan adanya kepercayaan tertentu bahwa gangguan mental disebabkan dari garis keturunan keluarga (Krupnick \& Melnikoff, 2012; Mohr, Howard, Julian, Vella, Catledge, \& Feldman, 2006). Harvey dan Gumport (2015) menuliskan ringkasan mengenai hambatan-hambatan yang dapat diubah dan kemungkinan solusi untuk penanganan psikologi berbasis bukti empiris untuk gangguan mental.

Tabel 2

Hambatan dan Solusi Alternatif Penanganan Psikologi Berbasis Bukti Empiris

\begin{tabular}{|c|c|c|}
\hline & Hambatan-Hambatan & Solusi Alternatif \\
\hline Level Pasien & $\begin{array}{l}\text { - Masalah-masalah seperti transpor- } \\
\text { tasi, perawatan anak, perjanjian pada } \\
\text { waktu dan tempat yang nyaman, } \\
\text { identifikasi terapis yang ahli, meng- } \\
\text { hadiri sesi-sesi tepat waktu, dan } \\
\text { menghadapi stigma. } \\
\text { - Motivasi untuk menghadiri sesi-sesi } \\
\text { dan mematuhi rekomendasi pena- } \\
\text { nganan. } \\
\text { - Keyakinan bahwa penanganan tidak } \\
\text { membantu dan kurangnya kesadaran } \\
\text { akan layanan psikologi berbasis } \\
\text { bukti empiris. } \\
\text { - Menerima diagnosis yang akurat. }\end{array}$ & $\begin{array}{l}\text { - Membangun dan menguji model } \\
\text { konseptual hambatan-hambatan } \\
\text { pada level pasien untuk membantu } \\
\text { riset khusus mengenai itu dan usaha } \\
\text { membangun penanganan yang tepat. } \\
\text { - Melanjutkan untuk menerjemahkan } \\
\text { penelitian pada motivasi ke dalam } \\
\text { intervensi. } \\
\text { - Mengutamakan monitor luaran dan } \\
\text { mempublikasikan data luaran ke pu- } \\
\text { blik agar dapat diakses oleh pasien. } \\
\text { - Melanjutkan usaha untuk meningkat- } \\
\text { kan akurasi dan kecepatan diagnosis. }\end{array}$ \\
\hline
\end{tabular}




\begin{tabular}{|c|c|c|}
\hline & Hambatan-Hambatan & Solusi Alternatif \\
\hline Level Terapis & $\begin{array}{l}\text { - Keyakinan terapis bahwa layanan } \\
\text { psikologi berbasis bukti empiris } \\
\text { terlalu terstruktur dan berfokus pada } \\
\text { teknik, dan tidak selalu memberikan } \\
\text { luaran yang lebih baik. } \\
\text { - Preferensi terapis pada pendekatan } \\
\text { ekletik yang lebih fleksibel dan } \\
\text { menggabungkan beberapa strategi } \\
\text { dari berbagai orientasi teoritis. }\end{array}$ & $\begin{array}{l}\text { - Menyediakan pelatihan untuk bias- } \\
\text { bias kognitif. } \\
\text { - Mengadakan penelitian mengenai } \\
\text { bagaimana menyediakan pelatihan } \\
\text { seperti manual, workshop ahli, kur- } \\
\text { sus jangka panjang dengan supervisi, } \\
\text { program berbasis internet. } \\
\text { - Mengadakan penelitian untuk mem- } \\
\text { bangun seberapa banyak pelatihan } \\
\text { diperlukan untuk tipe-tipe layanan } \\
\text { psikologi berbasis bukti empiris yang } \\
\text { berbeda. }\end{array}$ \\
\hline
\end{tabular}

\begin{tabular}{llll}
\hline Level & Kesulitan identifikasi layanan - Membangun sumber definitif untuk \\
Penanganan & psikologi berbasis bukti empiris yang & identifikasi layanan psikologi berba- \\
& sesuai. & sis bukti empiris. \\
& Ruang untuk meningkatkan layanan & Melanjutkan untuk berinovasi. \\
& psikologi berbasis bukti empiris saat & - Transdiagnostic dan modularized \\
& ini. & treatment.
\end{tabular}

\begin{tabular}{|c|c|c|}
\hline Level Organisasi & $\begin{array}{l}\text { - Skeptis bahwa penanganan baru } \\
\text { akan membantu. } \\
\text { - Kurangnya dukungan administratif } \\
\text { dan waktu staf. } \\
\text { - Lingkungan yang penuh tekanan. }\end{array}$ & $\begin{array}{l}\text { - Meningkatkan iklim organisasi dan } \\
\text { mengurangi tekanan untuk penyedia } \\
\text { penanganan. } \\
\text { - Membangun pendekatan yang } \\
\text { inovatif. }\end{array}$ \\
\hline $\begin{array}{l}\text { Level } \\
\text { Pemerintah }\end{array}$ & $\begin{array}{l}\text { - Menyediakan biaya untuk gangguan } \\
\text { mental dengan nilai yang sama } \\
\text { dengan gangguan fisik. } \\
\text { - Struktur dan kebijakan perawatan } \\
\text { kesehatan. } \\
\text { - Kurangnya penyedia layanan psiko- } \\
\text { logi berbasis bukti empiris yang } \\
\text { terlatih. }\end{array}$ & $\begin{array}{l}\text { - Para ahli layanan psikologi berbasis } \\
\text { bukti empiris terlibat dalam advokasi } \\
\text { dan perkembangan kebijakan untuk } \\
\text { memastikan layanan psikologi berba- } \\
\text { sis bukti empiris sebagai penanganan } \\
\text { terdepan. } \\
\text { - Lebih banyak dokumen mengenai } \\
\text { efektivitas biaya jangka pendek dan } \\
\text { jangka panjang layanan psikologi } \\
\text { berbasis bukti empiris. }\end{array}$ \\
\hline
\end{tabular}

Sumber: Harvey, A. G., \& Gumport, N. B. (2015). Evidence-based psychological treatments for mental disorders: Modifiable barriers to access and possible solutions. Behaviour Research and Therapy, 68, p.3.

Memanfaatkan teknologi merupakan salah satu langkah inovatif untuk meningkatkan layanan psikologi, seperti yang diteliti oleh Mohr, Howard, Julian, Vella, Catledge, dan Feldman (2006) bahwa hambatan praktis dapat diatasi dengan telemental health program. Tutty, Ludman, dan Simon (2005) mengujicobakan layanan psikoterapi melalui telepon dengan pro58 gram cognitive behavior therapy. Hasilnya $80 \%$ pasien tetap mengikuti layanan ini sementara sisanya drop-out. Layanan ini dianggap sangat mudah diakses mengurangi waktu pasien meninggalkan pekerjaannya, hambatan transportasi, dan biaya dibandingkan perawatan dengan cara konvensional (tatap muka). Intervensi ini diberikan dengan prosedur yang telah Buletin Psikologi 
ditetapkan. Terapi ini dianggap cocok untuk wilayah yang sulit dijangkau karena keterbatasan transportasi dan stigma terhadap layanan kesehatan mental masih sangat tinggi. Sesi terdiri dari delapan kali pertemuan dan setiap sesi terdiri dari agenda dan edukasi khusus. Adapun pasien yang drop-out dikarenakan adanya resistensi dan kesiapan pasien terhadap eksperimen pikiran dan perilaku, terutama bagi mereka yang menghentikan pengobatan antidepressant. Bahan yang diberikan pada pasien yaitu surat balikan secara personal, koordinasi perawatan, self care plan, dan supervisi klinis.

Sheldon, Waxmonsky, Meir, Morris, Finkekstein, Sosa, dan Brody (2014) mengembangkan The Telephonic Assessment, Support, and Counseling Program (TACS) untuk pasien depresi di layanan kesehatan primer. Di Amerika penanganan depresi banyak dilakukan oleh Primary Care Psychologist, dan rekognisi terhadap depresi pun semakin meningkat, hanya saja kepatuhan untuk minum obat antidepressant sangat rendah. Target dari program ini adalah warga di perkotaan yang berstatus ekonomi di bawah rata-rata dengan beragam populasi etnik. TASC terdiri dari tim multidisiplin yaitu psikolog, dokter umum, ahli farmasi, dan pekerja sosial. Program ini menggunakan behavioral activation yang dinilai berbasis empiris dan dapat diberikan dalam waktu singkat. Adapun yang menjadi prosedur target yaitu edukasi mengenai depresi, kepatuhan pengobatan, dan strategi untuk mengajari pasien untuk memonitor suasana hati dan kegiatan rutin mereka untuk meningkatkan aktivitas kesehatan mereka. Selain itu juga diberikan Motivational Interviewing untuk meningkatkan kepatuhan minum obat dan konseling depresi. Keuntungan dari program ini adalah mampu menjangkau area geografis yang lebih luas dan juga dapat memilih terapis yang berbahasa sama dengan pasien.

\section{Evaluasi Program}

Salah satu komponen terpenting dari sebuah evaluasi program adalah kepuasan pasien. Terdapat dua tipe harapan pada pasien mengenai penanganan kesehatan mental, yang pertama harapan mengenai hasil dari penanganan, yang kedua adalah apakah penanganan sesuai dengan apa yang diharapkan pasien. Hundt, Armento, Porter, Cully, Kunik, dan Stanley (2013) meneliti tentang kepuasan pasien gangguan kecemasan menyeluruh yang diberikan penanganan CBT dan penanganan biasa. Hasilnya menunjukkan bahwa kepuasan pasien gangguan kecemasan menyeluruh dengan penanganan CBT lebih tinggi dibandingkan penanganan biasa dengan menggunakan desain randomized controlled trial (RCT).

Kepuasan pasien berasosiasi dengan kredibilitas penanganan, harapan akan penanganan, dukungan sosial, dan adanya perubahan dengan gejala depresi dan kecemasan pasien pada keseluruhan sampel, namun hanya kredibilitas penanganan dan kepatuhan pasien yang memprediksi kepuasan pasien dalam kelompok CBT. Pasien dewasa yang memiliki keyakinan kuat akan tujuan dari penanganan dan mengikuti rekomendasi terapis melaporkan kepuasan yang lebih besar pada saat akhir penanganan. Kepatuhan menjadi mediator dalam hubungan antara kredibilitas penanganan dan kepuasan pasien dalam jangka waktu segera setelah penanganan dan tiga hingga enam bulan kemudian (Hundt et al., 2013). Dengan kata lain penanganan yang memiliki pengaruh pada pasien akan memengaruhi persepsi pasien dan meningkatkan kepatuhannya untuk menjalankan rekomendasi terapis 
sehingga meningkatkan kepuasannya terhadap penanganan.

\section{Penutup}

Ditemukannya indikator kasus gangguan mental di layanan kesehatan primer adalah nyata adanya. Dapat dikatakan bahwa di tingkat layanan kesehatan primer dasar dibutuhkan adanya layanan psikologi. Namun demikian, layanan psikologi yang diberikan di layanan kesehatan primer tidak serta merta dapat diterima dengan mudah dan efektif, dikarenakan literasi kesehatan mental masyarakat yang masih rendah, stigma yang melekat terkait gangguan mental, dan juga perlunya penguatan penggunaan teknik-teknik layanan psikologi yang cocok untuk dapat diterapkan di level dasar dan proses kerja di layanan kesehatan primer. Maka dari itu, telah banyak artikel ilmiah dan penelitianpenelitian mengenai berbagai jenis layanan psikologis yang dapat diterapkan di layanan kesehatan primer. Salah satu jenis layanan psikologis yang dimaksud adalah inovasi perawatan kolaboratif dan pemanfaataan teknologi dalam layanan psikologi yang dapat menjangkau seluruh lapisan masyarakat dan area geografis yang lebih luas. Tentu saja masih banyak pekerjaan rumah, yang mungkin secara teknis harus diselesaikan. Akan tetapi penting bagi para praktisi kesehatan mental dan pengambil kebijakan untuk mulai berpikir ke depan mengenai layanan psikologi di layanan kesehatan primer yang dapat dijangkau dengan mudah, murah, preventif, dan ramah budaya.

\section{Daftar Pustaka}

Ansseau, M., Dierick, M., Buntinkx, F., Cnockaert, P., De Smedt, J., Van Den Haute, M., \& Mijnsbrugge, D. V. (2004).
High prevalence of mental disorders in primary care. Journal of Affective Disorders, 78, 49-55.

Bossema, E. R., de Haar, C.A., Westerhuis, W., Beenackers, B.P., Blom, B.C., Appels M.C., van Oeveren, C.J. (2011). Psychoeducation for patients with a psychotic disorder: effects on knowledge and coping. Prim Care Companion CNS Disord. 13(4). doi: 10.4088/PCC.10m01116.

Burns, J. K. (2014). The burden of untreated mental disorders in KwaZulu-Natal Province-Mapping the treatment gap. South African Journal of Psychology, 20(1), 6-10.

Corrigan, P. W., Mittal, D., Reaves, C. M., Haynes, T. F., Han, X., Morris, S., \& Sullivan, G. (2014). Mental health stigma and primary health care decisions. Psychiatry Research, 218, 35-38.

Cuijpers, P., Geraedts, A. S., van Oppen, P., Andersson, G., Markowitz, J. C., \& van Straten, A. (2011). Interpersonal psychotherapy for depression: A metaanalysis. American Journal of Psychiatry, 168(6), 581-592.

Dinas Kesehatan DIY. (2015). Strategi kesehatan jiwa peluang bagi psikolog. Dipresentasikan pada Seminar Mental Health Week yang diadakan oleh Center for Public Mental Health $(\mathrm{CPMH})$, Fakultas Psikologi Universitas Gadjah Mada (UGM), Yogyakarta.

Donker, T., Griffiths, K. M., Cuijpers, P., \& Christensen H. (2009). Psychoeducation for depression, anxiety, and psychological distress: A meta-analysis. BMC Medicine, 7(79), 1-9.

Goncalves, D. A., Fortes, S., Campos, M., Ballester, D., Portugal, F. B., Tofoli, L. F., Gask, L., Mari, J., \& Bower, P. (2013). Evaluation of a mental health training intervention for multidisciplinary teams Buletin Psikologi 
in primary care in Brazil: A pre-and posttest study. General Hospital Psychiatry, 35, 304-308.

Grandes, G., Montoya, I., Arietaleanizbeaskoa, M. S., Arce V., \& Sanchez, A. (2011). The burden of mental diorders in primary care. European Psychiatry, 26, 428-435.

Hanlon, C., Fekadu, A., \& Patel, V. (2014). Interventions for Medical Disorders in V. Patel, H. Minas, A. Cohen, \& M. J. Prince (Eds.), Global mental health: Principles and practice (pp. 401-424). New York: Oxford University Press.

Harvey, A. G., \& Gumport, N. B. (2015). Evidence-based psychological treatments for mental disorders: Modifiable barriers to access and possible solutions. Behaviour Research and Therapy, 68, 1-12.

Hundt, N. E., Armento, M. E. A., Porter, B., Cully, J. A., Kunik, M. E., \& Stanley, M. (2013). Predictors of treatment satisfaction among older adults with anxiety in a primary care psychology program. Evaluation and Program Planning, 37, 5863.

Jauregui, A., Ponte, J., Salgueiro, M., Unanue, S., Donaire, C., Gomez, M. C., Burgos-Alonso, N., \& Grandes, G. (2015). Efficacy of a cognitive and behavioural psychotherapy applied by primary care psychologist in patients with mixed anxiety-depressive disorder: A research protocol. BMC Family Practice, 16, 39, 1-7.

Kementerian Kesehatan RI. (2013). Riset Kesehatan Dasar (RISKESDAS) 2013. Laporan Penelitian (tidak dipublikasikan). Jakarta: Badan Penelitian dan Pengembangan Kesehatan.

Kohn, R., Saxena, S., Levav, I., \& Saraceno, B. (2004). The treatment gap in mnetal health care. Bulletin of the World Health Organization, 82(11), 858-866.
Krupnick, J. L., \& Melnikoff, S. E. (2012). Psychotherapy with low-income patients: Lesson learned from treatment studies. Journal of Contemporary Psychotherapy, 42, 7-15.

McBain, R., Salhi, C., Morris, J. E., Salomon, J. A., \& Betancourt, T. S. (2012). Disease burden and mental health system capacity: WHO atlas study of 117-lowand middle-income countries. The British Journal of Psychiatry, 201, 444-450.

Mclnnis, M. G., \& Merajver, S. D. (2011). Global mental health: Global strengths and strategies task-shifting in a shifting health economy. Asian Journal of Psychiatry, 4, 165-171.

Mohr, D. C., Howard, I., Julian, L., Vella, L., Catledge, C., \& Feldman, M. D. (2006). Barriers to psychotherapy among depressed and non-depressed primary care patients. The Society of Behavioral Medicine, 32(3), 254-258.

Mueser, K. T., \& McGurk, S. R. (2004). Schizophrenia. Lancet, 363, 2063-2072.

Ngui, E. M., Khasakhala, L., Ndetei, D., \& Roberts, L. W. (2010). Mental disorders, health inequalities and ethics: A global perspective. International Review of Psychiatry, 22(3), 235-244.

Patel, V. (2007). Mental health in low-and middle-income countries. British Medical Bulletin, 81, 81-96.

Prawitasari, J. E. 2011. Psikologi klinis: Pengantar terapan mikro dan makro. Jakarta: Erlangga.

Putri, A. S., Martiningtyas, M. A. D., Sagala, A. E. S. B., Erawan, G. N., Yana, I. P. A., Martiningtyas, D., Matulu, S.,... \& Subandi. (2013). Era baru kesehatan mental Indonesia: Sebuah kisah dari desa siaga sehat jiwa (DSSJ). Jurnal Psikologi, 40(2), 169-180. 
Rathod, S., Kingdon, D., Smith, P., \& Turkington, D. (2005). Insight into schizophrenia: The effects of cognitive behavioural therapy on the components of insight and association with sociodemographics-data on a previously published randomised controlled trial. Schizophrenia Research, 74, 211-219.

Reifels, L., Bassilios, B., Nicholas, A., Fletcher, J., King, K. Ewen, S., \& Pirkis, J. (2015). Improving access to primary mental healthcare for indigenous Australians. Australian \& New Zealand Journal of Psychiatry, 49(2), 118-128.

Retnowati, S. (2011). Psikolog PUSKESMAS: Kebutuhan dan Tantangan bagi Profesi Psikologi Klinis Indonesia. Pidato Pengukuhan (tidak dipublikasikan). Yogyakarta: Fakultas Psikologi UGM.

Roca, M., Gili, M., Garcia-Garcia, M., Salva, J., Vives, M., Campayo, G., \& Comas, A. (2009). Prevalence and comorbidity of common mental disorders in primary care. Journal of Affective Disorders, 119, 52-58.

Russel, S., Russel, P. S., Kaur, M. S. D., Nair, M. K. C., \& Darilin, D. (2012). Priority mental health disorders of children and adolescents in primary-care pediatric settings in India 3: Psychotherapy and other non-pharmacological interventions. Indian Journal of Pediatrics, 79(1), S33-S38.

Sheldon, C., Waxmonsky, J. A., Meir, R., Morris, C., Finkekstein, L., Sosa, M., \& Brody, D. (2014). Telephone assessment, support, and counseling for depression in primary care medical clinics. Cognitive and Behavioral Practice, 21, 282295.

Steinert, C., Hofmann, M., Kruse, J., \& Leichsenring, F. (2014). Relapse rates after psychotherapy for depression - stable long-term effects? A metaanalysis. Journal of Affective Disorders, $168,107-118$.

Tolin, D. F. (2010). Is cognitive behavioral therapy more effective than other therapies? A meta-analytic review. Clinical Psychology Review, 30(6), 710720.

Tursi, M. F. S., Baes, C. W., Camacho, F. R. B., Tofoli, S. M. C., \& Juruena, M. F. (2013). Effectiveness of psychoeducation for depression: A systematic review. Australian \& New Zealand Journal of Psychiatry, 47(11),1019-1031.

Tutty, S., Ludman, E. J., \& Simon, G. (2005). Feasibility and acceptability of a telephone psychotherapy program for depressed adults treated in primary care. General Hospital Psychiatry, 27, 400410.

Verdoux, H., Cortaredona, S., Dumesnil, H., Sebbah, K., \& Veryer, P. (2014). Psychotherapy for depression in primary care: A panel survey of general practitioners' opinion and prescribing practice. Social Psychiatry and Psychiatric Epidemiology, 49, 59-68.

Widiyani, R. (2013, Juli 16). Pasien gangguan jiwa bisa dirawat di lingkungan masyarakat. Kompas. Diunduh dari http://health.kompas.com/read/2013/07/16/1 047559/Pasien.Gangguan.Jiwa.Bisa.Dirawa t.di.Lingkungan.Masyarakat.

Wolf, N. J., \& Hopko, D. R. (2008). Psychosocial and pharmacological interventions for depressed adults in primary care: A critical review. Clinical Psychology Review, 28, 131-161.

World Health Organization. (2001). The world health report 2001 - mental health: New understanding, new hope. Geneva: WHO Library Cataloguing-inPublication Data. 